\title{
Repetitorium anatomicum
}

von

\author{
Prof. Dr. med. G. Broesike
}

Mit 73 zumeist mehrfarbigen Abbildungen im Text und einer Tafel

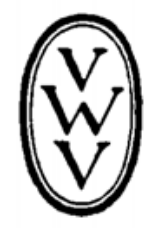

Berlin und Leipzig 1919

Vereinigung wissenschaftlicher Verleger Walter de Gruyter \& Co.

vormals G.J. Goschen'sche Verlagshandlung :: J. Guttentag, Verlagsbuchhandlung :: Georg Reimer :: Karl J. Trubner :: Vett \& Comp. 
Alle Rechte, einschlieBlich des Übersetzungsrechts, vorbehalten.

Druck von Metzger \& Wittig in Leipzig. 